American Journal of Biochemistry and Biotechnology 4 (2): 130-145, 2008

ISSN 1553-3468

(C) 2008 Science Publications

\title{
A Microscopic Study of Language-Related Cortex in Autism
}

\author{
Edith López-Hurtado and Jorge J. Prieto \\ Department of Histology and Anatomy, University Miguel Hernandez, 03550-San Juan, Spain
}

\begin{abstract}
Impaired language function is a principle criterion for the diagnosis of autism. The present study of brain from age-matched autistic and control subjects compared brain regions associated with the production and processing of speech. Wernicke's area (Brodmann 22, speech recognition), Broca's area (Brodmann 44, speech production) andthe gyrus angularis (Brodmann 39, reading) from autistic subjects (7-44 years of age) and control subjects (8-56 years of age) were examined microscopically. Striking differences in the density of glial cells, the density of neurons andthe number of lipofuscincontaining neurons were observed in the autistic group compared with the control group. The mean density of glial cells was greater in the autistic cohort than controls in area $22(p<0.001)$, area 39 $(\mathrm{p}<0.01)$ andarea $44(\mathrm{p}<0.05)$. The density of neurons was lesser in autism in area $22(\mathrm{p}<0.01)$ and area $39(\mathrm{p}<0.01)$. The autistic group exhibited significantly greater numbers of lipofuscin-containing cells in area $22(\mathrm{p}<0.001)$ and area $39(\mathrm{p}<0.01)$. The results are consistent with accelerated neuronal death in association with gliosis and lipofuscin accumulation in autism after age seven. Production of lipofuscin (a matrix of oxidized lipid and cross-linked protein more commonly associated with neurodegenerative disease) is accelerated under conditions of oxidative stress. Area 22 in autism evidenced the greatest glial increase, the greatest neuronal decrease andthe greatest increase of non-specific cells containing lipofuscin, which itself may contribute to greater free-radical generation in brain.
\end{abstract}

Key words: Autism, cerebral cortex, gliosis, lipofuscin, oxidative stress

\section{INTRODUCTION}

Autism, a developmental neuropsychiatric disease, is diagnosed in early childhood and features social and communication deficits, restricted and repetitive behaviors and interests anda characteristic course ${ }^{[1]}$. Relatives of autistic subjects are more likely to manifest social, cognitive andpsychiatric deficits ${ }^{[2-4]}$ anda milder form of autism is unassociated with mental retardation $^{[5]}$. It is strongly suggested that outside the formal diagnosis of autism, there exists an unexpectedly large population with milder, but significant, social and communication deficits ${ }^{[6]}$.

While functional alterations in cortical auditory and language processing in autism are reported ${ }^{[7]}$, language-related cortex of autistic subjects has not been subjected to systematic microscopic examination. Language is a complex brain function, involving numerous subcortical and cortical areas, including areas for primary and secondary auditory processing. For this study we analyzed three higher-order cortical areas involved in the processing of language and production of speech: Wernicke's area, Broca's area and the angular gyrus in the brains from autistic and control subjects.

Wernicke's area (Brodmann area 22) is a supplementary-auditory section of neocortex in the left temporal lobe which mediates the understanding of auditory words. Wernicke's aphasia, an inability to decipher the meanings of the speech sounds, results from damage to area 22. Broca's area is a premotor region of the neocortex located in the left frontal lobe (Brodmann areas 44 and 45) which mediates the production and control of human speech. Lesions to this area (Broca's aphasia) produce speech problems, but do not affect semantic or basic syntactic abilities. Wernicke's and Broca's areas are connected by the arcuate fasciculus; conscious language output originating in Wernicke's area is carried via the arcuate fasciculus to Broca's area, where a detailed and coordinated program for vocalization is compiled and sent to the facial zone of the motor cortex. The angular gyrus (Brodmann area 39) is a small region behind Wernicke's area which contains regions of the occipital, parietal andtemporal lobes. Area 39 facilitates

Corresponding Author: Jorge J. Prieto, Department of Histology and Anatomy, University Miguel Hernandez, Carretera Valencia s/n, 03550-San Juan, Alicante, Spain 
interaction of visual and auditory brain cortex andhas been implicated in alexia, dyslexia ${ }^{[8]}$ and agraphia.

Hypothetically, structural alteration of one or more of these cortical areas might contribute to the communication impairment found in autism. The purpose of this study was to assess the microscopic anatomy of Wernicke's area, Broca's area andthe angular gyrus in preserved brain of accuratelydiagnosed autistic subjects in comparison to agematched controls. The pattern of cortical layering, relative thickness of cortical layers andneuronal and glial densities for each layer was determined. Glial density, neuronal density andnumber of nonspecific lipofuscin-containing cells was determined for each subject. The data allowed assessment of each parameter as a function of subject age.

\section{MATERIALS AND METHODS}

Human subjects: The tissue required for this study was obtained from the Harvard Brain Tissue Resource Center, the Human Tissue Bank at the Universitiy of Miami andthe NICHD Brain and Tissue Bank for Neurodevelopmental Disorders at the University of Maryland, as facilitated by the Autism Tissue Program. Medical history and documentation of autism by Autism Diagnostic Interview (ADI-R) was provided for each subject. Formalin-preserved blocks from the lefthemisphere were from eight autistic and seven control subjects:

\begin{tabular}{llllll}
\hline Autism & & & \multicolumn{3}{l}{ Control } \\
Age & Sex & Identifier & Age & Sex & Identifier \\
\hline 7 & male & UMB-797 & 8 & male & UMB-662 \\
9 & male & B-4925 & 17 & male & B-2234 \\
10 & male & BTB-3714 & 22 & male & B-4981 \\
14 & male & B-4323 & 30 & male & B-4211 \\
25 & male & BTB-3711 & 46 & male & B-4192 \\
26 & male & B-5000 & 52 & male & BTB-3692 \\
31 & male & B-4871 & 56 & male & B-4503 \\
44 & male & B-4541 & & & \\
\hline
\end{tabular}

Tissue preparation: Formalin-fixed postmortem tissue blocks from areas 22, 39 and 44, were stored in $10 \%$ phosphate-buffered formalin. Portions of each block were immersed in $20 \%$ sucrose cryoprotectant, then serially sectioned in perpendicular orientation to the pial surface with a sliding microtome, at $100 \mu \mathrm{m}$. Adjacent series of sections were stored at $-20^{\circ} \mathrm{C}$ in a solution made of $3 \%$ glycerol, $3 \%$ ethylene glycol, $1 \%$ phosphate buffer (PB) anddistilled water; alternate sections were stained with cresyl violet $(0.1 \%)$ in order to visualize laminar boundaries. For lipofuscin study, sections were coverslipped with Fluoromount G (Aname 17984-25). All sections were coded and randomized to conform with strict double-blind methodology.

Sample preparation for cell-counts involved several steps. Blocks were divided to provide a portion for microdissection and post-fixation with $2 \% \mathrm{OsO}_{4}$ in $0.9 \% \mathrm{NaCl}$ containing $1.5 \%$ potassium ferrycianure (Sigma, St Louis, MO), for 1 h. Tissue was dehydrated with propylene oxide and flat-embedded in Epon; 1 $\mu \mathrm{m}$-thick sections were produced with a diamond knife, then dried on glass slides andstained with basic toluidine blue (borate buffer, $\mathrm{pH} 11$ ).

Immunohistological staining: Astrocytes were stained with polyclonal antibody to glial fibrillary acidic protein (GFAP; DAKO, Denmark). The sections were rinsed initially with TBS $(0.05 \mathrm{M}$ Tris and0.15 M $\mathrm{NaCl}$ ), $\mathrm{pH} 7.5$, then pre-treated with a solution of $50 \%$ ethanol and $1 \%$ hydrogen peroxide (Sigma, St Louis, $\mathrm{MO}$ ) in phosphate-buffered saline (PBS) for $30 \mathrm{~min}$ in order to remove endogenous peroxidase activity, then rinsed in PBS andsubsequently incubated in 1:5 normal goat serum for $30 \mathrm{~min}$ in order to block non-specific staining. Then primary anti-GFAP antibody was applied at 1:200 dilution for $2 \mathrm{~h}$ at $4^{\circ} \mathrm{C}$, followed by rinse with PBS and incubation with biotinylated goat anti-mouse antibody 1:200 in PBS for $1 \mathrm{~h}$ at room temperature andsubsequent processing by the avidinbiotin-peroxidase method (Vectastain ABC immunoperoxidase kit: Vector, Burlingame, CA). DAB (3.3'-diaminobenzidine tetrahydrochloride: Sigma, St Louis, MO) was used as the chromogen. Sections were mounted on glass slides, dehydrated, cleared in xylene and coverslipped.

Morphometric analyses: An optical fractionation method was employed to estimate cell density. This procedure is based on a random systematic choice of cortical tissue samples andperformed by means of a regular, previously-designed grid of counting frames $(100 \times 100 \mu \mathrm{m})$. An average of 4 fields per cortical layer was counted in each section, resulting in an average of 24 fields for each sample in every cortical area studied. The cells were counted only if their somata fell entirely within the frame area. Cell density was calculated by dividing the total number of cells in each layer by the surface area of the frame (or in the examination of cortical colums, division by the area of the cortical column). These data were expressed as number of cells per $\mathrm{mm}^{2}$. 
The randomized and codified sections were observed with a $100 \times$ oil immersion lens on a Leica DMRB light microscope. $200 \mu \mathrm{m}$-wide columns, spanning pia to white matter, were examined and plotted on paper with respect to cortical layers. Neurons and glial cells were distinguished carefully. Neuronsusually, but not always larger than glial cells were distinguishable by their non-spherical shape, stained cytoplasm andvisible nucleolus. In contrast, glial cells were identified by the absence of cytoplasmic staining, small size andround shape.

Thickness of the cortical mantle was assessed with a Leica PL FLUOTAR lens, A.N. 0.12, which was used to represent a column through the entire extent of the cortical mantle on graph paper. The total cortical thickness was noted to vary noticeably among different regions of a given cortical area, thus precluding direct comparisons of absolute values. Hence, cortical thickness was reported as percentage of total cortical thickness.

Lipofuscin identification and quantification: Lipofuscin-containing cells are readily identifiable by autofluorescence. A Zeiss III RS fluorescence microscope with an HBO 50W AC super pressure mercury lamp was utilized for determination of number of cells containing lipofuscin. Both 365 and $450 \mathrm{~nm}$ excitation filters were employed andcell counts and cell-density calculations were performed as previously described for glial and neuronal cells.

Reproduceable photographs of intracytoplasmic lipofuscin aggregates were obtained using a confocal laser-scanning microscope (Leica TCS SL) equipped with a Hellion/Neon laser and a 60×oil objective (Leica Plan Apochromat). The tissue sections were excited at 488 and $568 \mathrm{~nm}$ wavelengths andthe image was reconstructed from a stack of 10 consecutive confocal planes.

Quantitative analysis of the size of the intracytoplasmic lipofuscin aggregates was performed on single optical images for each brain section. By employing a 60×oil lens in a random-systematic manner, a region of interest (ROI) was selected by computer andaligned over layer I. The sampling ROI was moved vertically through all cortical layers andevery deposit of lipofuscin contained within the select ROI was outlined with a mouse cursor. The quantification of the lipofuscin area was accomplished with an Image Analysis System (Soft Imaging System $\mathrm{GmbH}$, Münster, Germany) program.
Statistical analysis: Cell counts across hexalaminar cortical columns were obtained in an uninterrupted series of counting boxes that spanned the entire depth of cortex from the pial surface to the underlying white matter. Four distinct cortical probes were obtained for each brain area. The cell density for each case was determined by dividing the number of cells counted in each sample by the total area of the chosen region. The data were expressed as the Mean \pm SD of the sample.

The statistical Student's t-test was used to compare the mean values from individual morphometric parameters between autistic and control subjects of matching ages. The confounding potential influence of postmortem delay andfixation interval were evaluated using the analysis of covariance, which demonstrated no significant relationship.

\section{RESULTS}

Analysis of cortical laminar thickness: The thickness of cortical layers in relation to total cortical thickness in the three brain areas examined were not significantly different between autistic and control cohorts (Table 1).

\section{Longitudinal analysis of control data:}

Density of glial cells: In controls, the density of glial cells in full-depth cortical sections increased in all three brain areas as a function of age (Fig. 1a-c). Thus, in each brain area, glial density was approximately twice as high in sixth-decade subjects, as compared to the youngest subject, age 8 . A steep rise in glial cells was measured in area 39 at age $30(p=0.0212)$ and in area 44 at age $30(\mathrm{p}=0.0007)$ (Fig. 2a-c). Generally, the decrement in glial density was most pronounced in layers III, V and IV (Table 2).

Neuronal density: In controls, a significant decline in neuronal density was evident in full-depth cortical sections of area 22 (by $40 \%$ from age 8 to age 56 , $\mathrm{p}=0.0187$ ), but not in area 39 or 44 (Fig. 2d,e.f) Laminar analysis (Table 3) demonstrated age-related declines in all cortical layers of area 22, particularly in layers II (reduced $40 \%$ from age 8 to age 56, $\mathrm{p}=0.0025$ ) and IV (reduced $35 \%$ from age 8 to 56 , $\mathrm{p}=0.0058)$. In area 39 , a pronounced decrement was observed in layer V (50\% from age 8 to $56, \mathrm{p}=0.0057)$ and in area 44, there was a moderate decline in neuronal density in layers II (reduced $21 \%$ from age 8 to age $56, \mathrm{p}=0.0363$ ).

Lipofuscin-containing cells: The lipofuscin cell-count (Table 4) did not differentiate between neuronal and 
Am. J. Biochem. \& Biotech., 4 (2): 130-145, 2008

Table 1:. Percentage of total cortical thickness. \%: percentage. SD: standard deviation

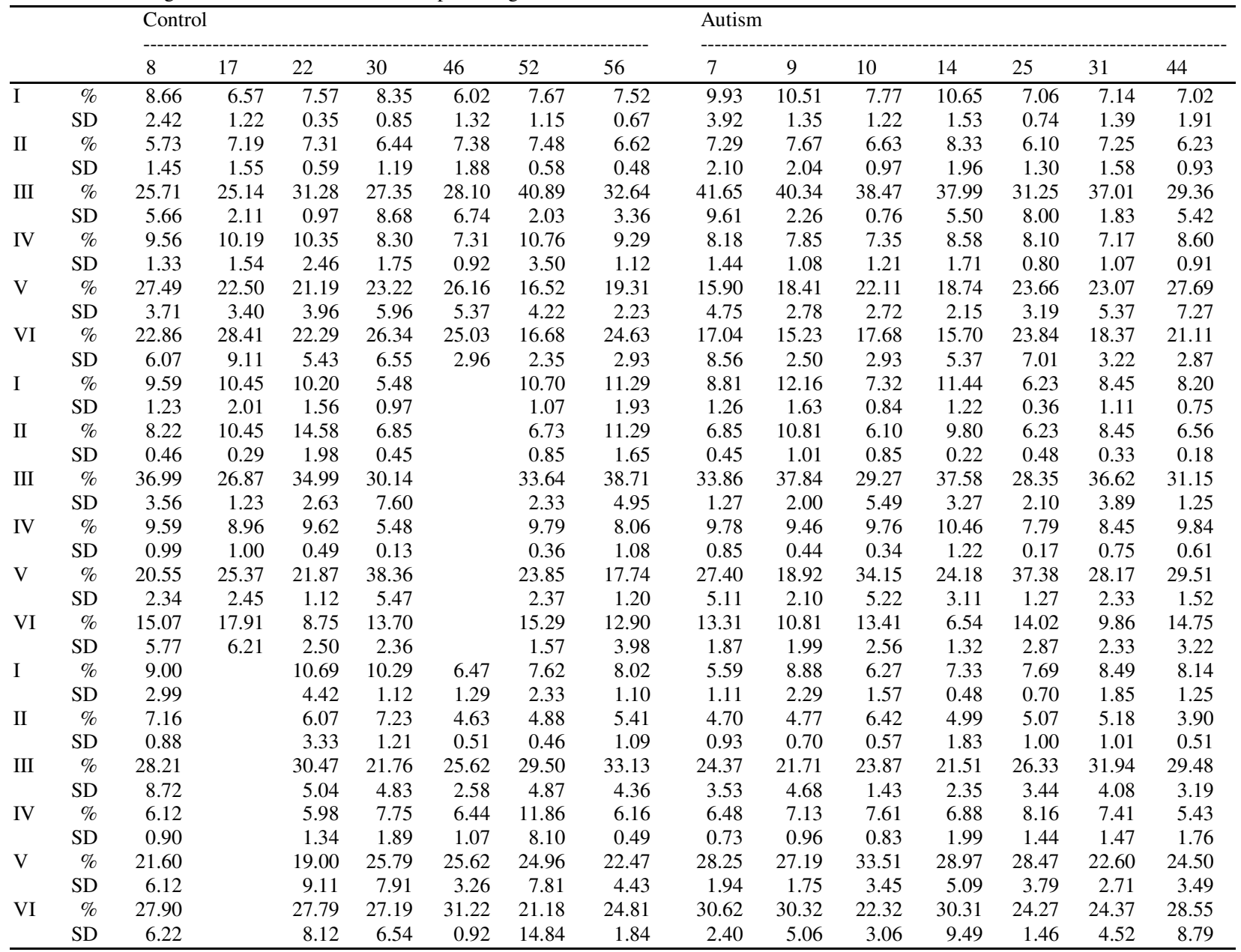
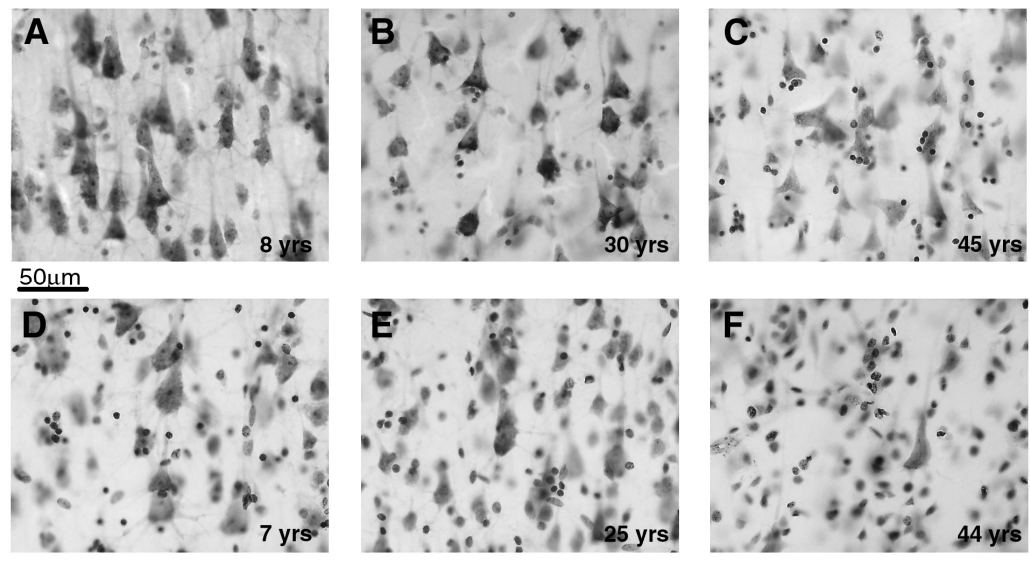

Fig. 1: Photomicrographs illustrating neurons and glial cells using Nissl staining from Wernicke's (area 22). Control cases (A, B and C) contrast with autistic cases (D, E and F). As expected with aging, the older control subject (C) demonstrated increased density of glial cells and decreased density of neurons. The changes are accelerated in autism, including the cohort's youngest subject, age 7 (D) 


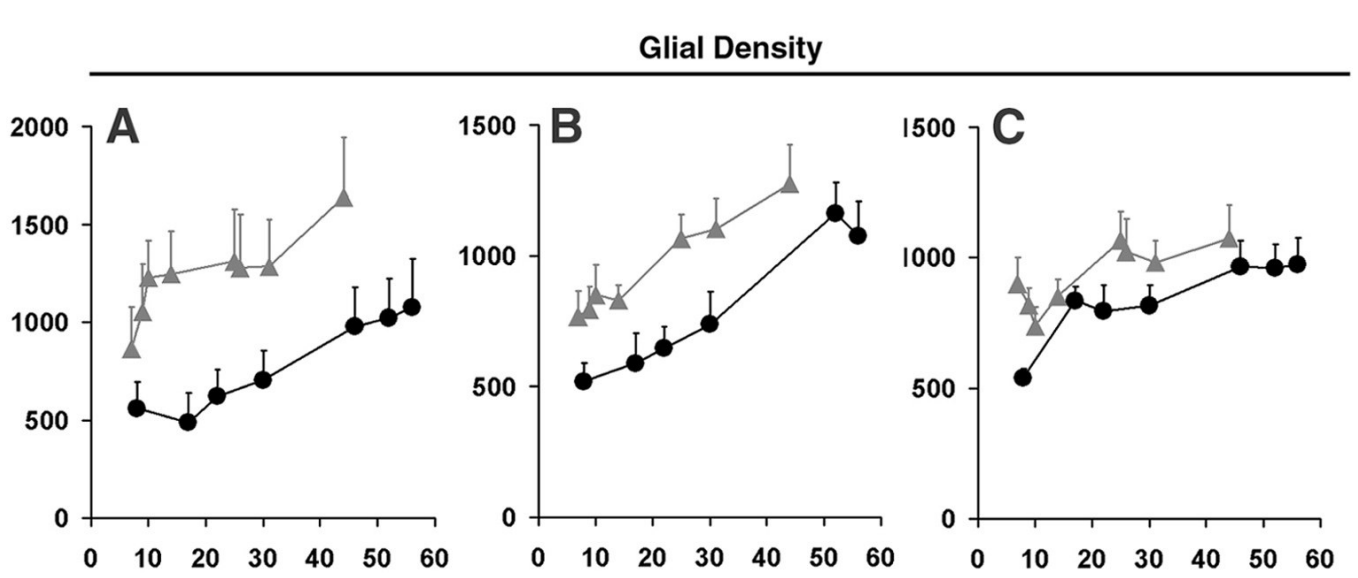

Neuronal Density
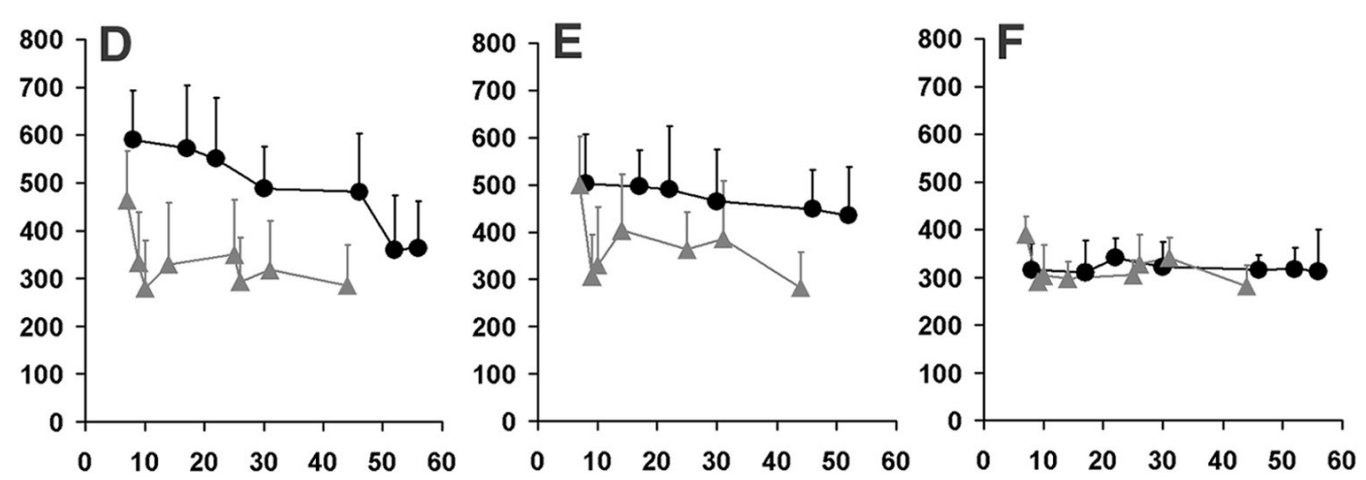

Density of Lipofuscin-Containing Cells
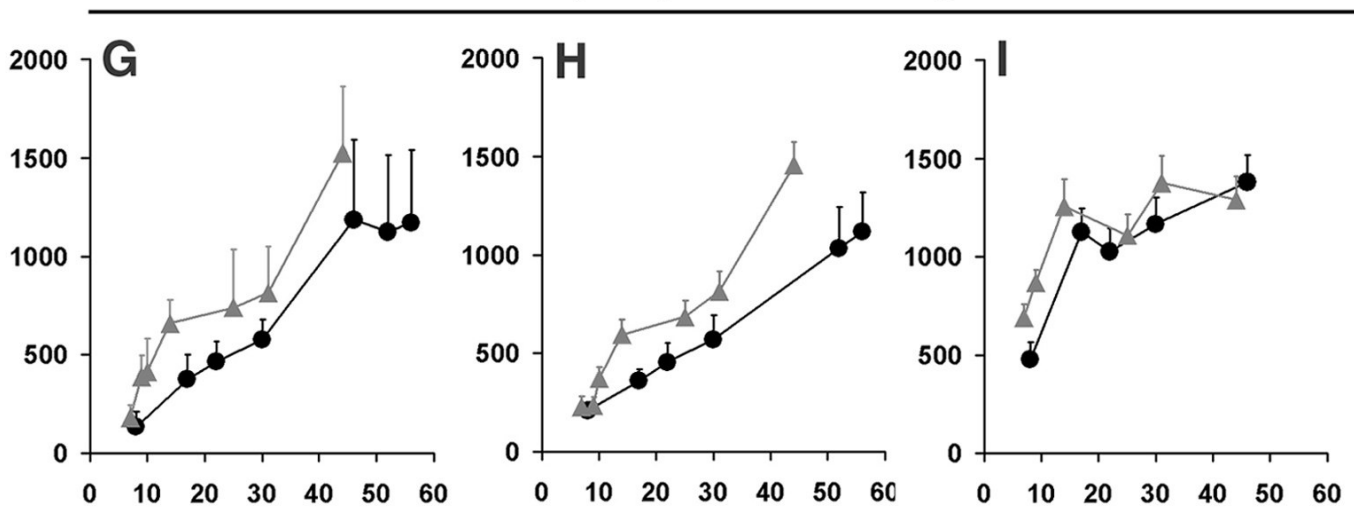

Fig. 2: Density of glial cells, density of neurons, and density of lipofuscin-containing cells in brain areas 22,39 and 44. Glial cells (A, B and C), neurons (D, E and F), and cells with lipofuscin (G, H and I) were counted along complete cortical columns. Values for controls subjects are graphed in black, for autistic subjects in gray. The horizontal axes correspond to age in years of the subjects, and the vertical axes represent the number of cells $\mathrm{mm}^{-2}$ 
Am. J. Biochem. \& Biotech., 4 (2): 130-145, 2008

Table 2:. Number of glial cells $\mathrm{mm}^{-2}$. M: Mean. SD: standard deviation. T: total cell density

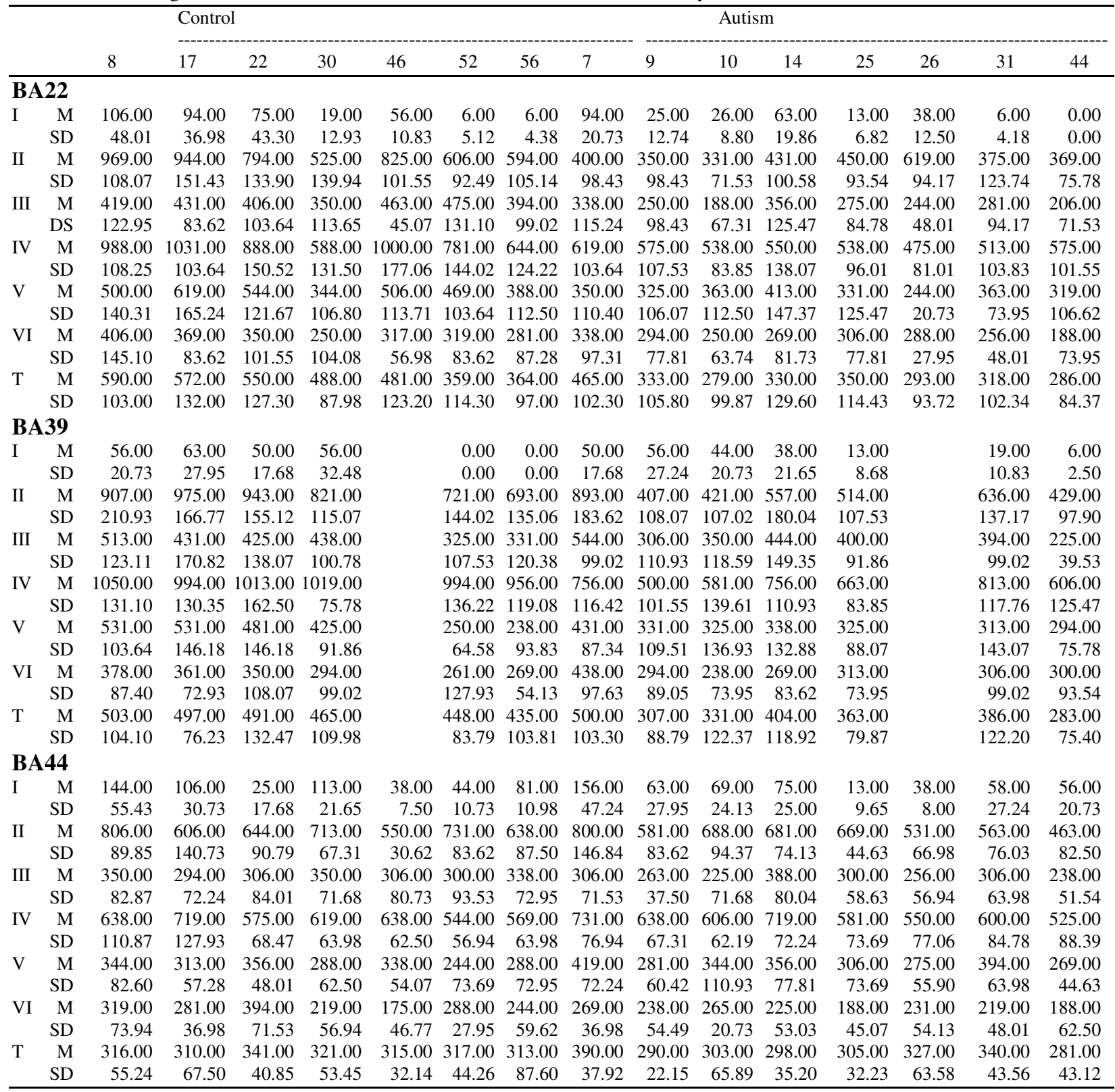

glial cells. In controls, the number of lipofuscincontaining cells in full-depth cortical samples increased in all three brain areas from age 8 to age 56 in area 22 by $770 \%(\mathrm{p}=0.0015)$; area 39 by $430 \%$ $(\mathrm{p}=0.0001)$; and from age 8 to age 46 in area 44 by $189 \%(\mathrm{p}=0.0001)$. At corresponding ages, the lipofuscin cell-count was consistently higher in area 44 than in areas 22 or 39 (Fig. 2g-i). Laminar analysis demonstrated greatest gross number of cells containing lipofuscin in layers II and IV, layers with high cell density. Qualitatively, the size of individual lipofuscin aggregates appeared greatest in layers III and V, also the site of largest pyramidal cells (Fig. 3).

\section{Longitudinal analysis of autism data}

Density of glial cells: In the autistic cohort, the density of glial cells (Table 2) in full-depth cortical sections increased significantly over time in area 22 (89\% from age 7 to age $44, p=0.0061)$ and in area $39(66 \%$ from age 7 to age 44, p=0.0012), but not in area 44 

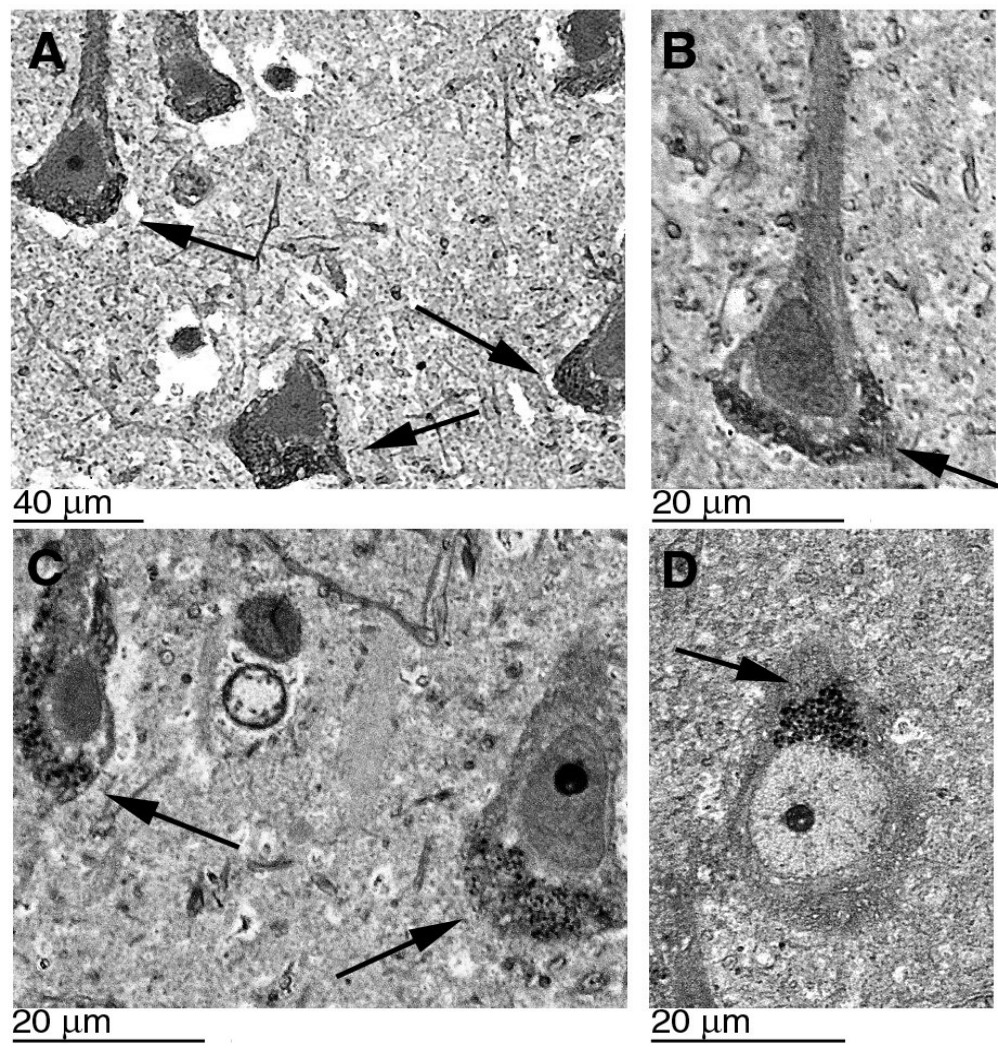

Fig. 3: Photomicrographs illustrating intracytoplasmic deposits of lipofuscin (arrows) in toluidine blue-stained semi-thin sections. The size of individual lipofuscin aggregates in the cerebral cortex of 17-year-old autistic subjects (B and D) are similar to those in the 52-year-old control subject (A and C)

(Fig. 2a-c). A steep rise in density of glial cells in area 22 between age 7 and $10(42 \%)$ was statistically significant $(\mathrm{p}=0.0424)$ andfollowed by a plateau from age 10 to age 31 .

Laminar analysis (Table 2) demonstrated statistically significant increase in density of glial cells in all layers of area 22; the least increase from age 7 to age 44 was seen in layer V and VI $(48 \%, \mathrm{p}=0.0080$; $65 \%, \mathrm{p}=0.0040)$. Although full-depth cortical sections did not demonstrate statistically-significant age-related changes in glial density, significant increases were found in layer III of area 39 (136\% from age 7 to age $44, \mathrm{p}=0.0026)$ and layers IV and V of area $44(97 \%$ increase from age 7 to age $44, \mathrm{p}=0.0041 ; 93 \%$ increase from age 7 to age $44, \mathrm{p}=0.0005)$.

Neuronal density: In the autistic cohort, decreased density of neurons over time in full-depth cortical samples was evident in all three brain areas, with a steep early decline followed by essential plateau in density of neurons no later than age 10 (Fig. 1d-f).
From age 7 to age 44, density of neurons decreased in area 22 by $39 \%(\mathrm{p}=0.0324)$, in area 39 by $43 \%(\mathrm{p}=$ $0.0144)$ and in area 44 by $30 \%(\mathrm{p}=0.0090)$. The most pronounced decrease in neuronal density from age 7 to age 44 in area 22 was layer VI $(39 \%, \mathrm{p}=0.0351)$, in area 39 , layer II $(57 \%, \mathrm{p}=0.0042)$ andin area 44 , layer II $(42 \%, \mathrm{p}=0.007)$ (Table 3$)$.

Lipofuscin-containing cells: In full-thickness cortical samples from autistic subjects, the number of lipofuscin-containing cells increased over time in all three areas of brain. Pronounced increases were found between age 7 and age 14 in area $22(69 \%, \mathrm{p}=0.014)$, area $39(149 \%, \mathrm{p}=0.0002)$ and area $44(45 \%$, $\mathrm{p}=0.002$ ) (Fig. 2g-i). In this younger subset, the range of lipofuscin-containing cells was 180 cells $\mathrm{mm}^{-2}$ in area 22, 226 cells $\mathrm{mm}^{-2}$ in area 39 and 690 cell $\mathrm{mm}^{-2}$ in area 44 (Table 4).

Transversal analysis: Comparison of autistic versus control subjects. 
Am. J. Biochem. \& Biotech., 4 (2): 130-145, 2008

Table 3: Number of glial cells $\mathrm{mm}^{-2}$. M: Mean. SD: standard deviation. T: total cell density

\begin{tabular}{|c|c|c|c|c|c|c|c|c|c|c|c|c|c|c|c|}
\hline \multirow[b]{2}{*}{ age } & \multicolumn{7}{|c|}{ Control } & \multicolumn{8}{|c|}{ Autism } \\
\hline & 8 & 17 & 22 & 30 & 46 & 52 & 56 & 7 & 9 & 10 & 14 & 25 & 26 & 31 & 44 \\
\hline \multicolumn{16}{|l|}{$\overline{\text { BA22 }}$} \\
\hline I M & 592 & 516 & 708 & 1000 & 992 & 1108 & 1141 & 916 & 975 & 942 & 817 & 1083 & 1050 & 842 & 1150 \\
\hline $\mathrm{SD}$ & 103.75 & 116.67 & 89.37 & 247.95 & 82.92 & 75.92 & 286.20 & 153.66 & 132.02 & 134.11 & 44.34 & 151.84 & & & 121.34 \\
\hline II $\mathrm{M}$ & 558 & 608 & 642 & 674 & 825 & 1209 & 1155 & 800 & 1200 & 1242 & 1400 & 1200 & 875 & 1267 & \\
\hline SD & 118.73 & 125.55 & 147.90 & 211.48 & 121.05 & 123.32 & 2192.03 & 197.20 & 154.56 & 138.19 & 131.23 & 158.11 & 147.90 & 187.08 & 4.80 \\
\hline III M & 491 & 350 & 430 & 475 & 817 & 967 & 992 & 717 & 758 & 1033 & 1258 & 983 & 824 & 1166 & \\
\hline SD & 168.94 & 98.60 & 131.23 & 170.78 & 121.34 & 224.85 & $\begin{array}{ll}5 & 190.58\end{array}$ & 178.73 & 173.81 & 227.30 & 173.81 & 186.34 & 103.75 & 187.08 & 7.31 \\
\hline \multirow{2}{*}{ IV } & 567 & 534 & 608 & 776 & 1133 & 1234 & 1283 & 992 & 1084 & 1316 & 1442 & 1217 & 1133 & 1750 & \\
\hline & 108.01 & 147.20 & 147.90 & 170.78 & 124.72 & 222.36 & 6153.66 & 176.97 & 167.50 & 167.50 & & & 179.51 & & 9.99 \\
\hline \multirow{2}{*}{ V M } & 467 & 459 & 675 & 917 & 1119 & 1108 & 1192 & 1058 & 1040 & 1163 & $11^{\prime}$ & 10 & 11 & 122 & \\
\hline & 110.55 & 125.55 & 178.54 & 189.54 & 158.77 & 243.10 & $\begin{array}{ll}0 & 216.51\end{array}$ & 155.23 & 220.32 & & & & & & \\
\hline \multirow{2}{*}{$\begin{aligned} & \text { VI } M \\
& \text { SD }\end{aligned}$} & 475 & 283 & 475 & 1025 & 1167 & 1140 & 1217 & 792 & 1192 & 1192 & 1184 & 11 & 109 & 12 & \\
\hline & 125.55 & 98.60 & 165.62 & 214.95 & 139.44 & 217.79 & 9206.16 & 144.10 & 157.01 & 3.27 & & & & & \\
\hline \multirow[b]{2}{*}{ SD } & 560 & 488 & 622 & 704 & 978 & 1023 & 1077 & 863 & 1054 & 1229 & 12 & 1311 & 1279 & 1287 & 163 \\
\hline & 134.63 & 152.37 & & & 198.22 & 201.00 & $\begin{array}{ll}0 & 243.20\end{array}$ & 216.13 & 243.87 & 186.56 & & & 267.88 & & 5.55 \\
\hline \multicolumn{16}{|l|}{ BA39 } \\
\hline \multirow{2}{*}{$\begin{array}{lr}\mathrm{I} & \mathrm{N} \\
& \mathrm{SL}\end{array}$} & 508 & & & & & 1042 & 1133 & & & & & & & & \\
\hline & 64.01 & 113.04 & & 111.4 & & 180.08 & 8200.00 & 95.38 & 72.17 & & .82 & & & & \\
\hline \multirow{2}{*}{$\begin{array}{ll}\text { II } & \mathrm{M} \\
& \mathrm{SD}\end{array}$} & 625 & 600 & 725 & 842 & & 1058 & 1100 & 1067 & 1167 & 132 & & 11 & & & \\
\hline & 138.19 & 154.56 & 144.10 & 147.9 & & 170.58 & 8204.12 & 198.61 & 182.57 & & 2.62 & & & & \\
\hline & 475 & 367 & 575 & 758 & & 992 & 1042 & 458 & 758 & 933 & 792 & 942 & & 78 & 10 \\
\hline & 155.23 & 126.93 & 208.67 & 138.19 & & 237.32 & 2134.11 & & 212.62 & & 7.90 & & & & 5.51 \\
\hline & 675 & 625 & 808 & 1008 & & 1125 & 1117 & 917 & 1083 & 1208 & & 12 & & & \\
\hline & 170.58 & 205.99 & 219.06 & & & 207.33 & 3186.34 & 7.50 & 2.40 & & & & & & 2.07 \\
\hline \multirow[t]{2}{*}{ V } & 650 & 467 & 633 & 992 & & 1092 & 1058 & 767 & 1042 & 103 & & 1217 & & & 12 \\
\hline & 144.34 & 3.37 & & & & 222.83 & $\begin{array}{ll}3 & 217.79\end{array}$ & & & & & & & & \\
\hline & 683 & 442 & 592 & 792 & & 1267 & 1283 & 89 & 1192 & 127 & 10 & 11 & & & 12 \\
\hline & 121.34 & 116.37 & 151.61 & 178.54 & & 190.03 & $3 \quad 172.40$ & 157.01 & 200.52 & & 47.90 & 212.62 & & 1.62 & 197.20 \\
\hline $\mathrm{T} \quad \mathrm{M}$ & 520 & 590 & 645 & 739 & & 1163 & 1077 & 767 & 794 & & & 1066 & & & \\
\hline SD & 67.87 & 112.78 & 86.56 & & & 117.98 & 8132.56 & 99.89 & 87.56 & & 56.76 & 90.87 & & & \\
\hline BA44 & & & & & & & & & & & & & & & \\
\hline M & 592 & & 508 & & & & 1008 & & & & & & & & \\
\hline SD & 76.93 & 123.89 & & & 95.42 & 139.45 & 5112.61 & & 82.24 & & & 53.49 & 86.86 & 99.43 & \\
\hline II $\mathrm{M}$ & 558 & 708 & 685 & 677 & & 750 & 1040 & 700 & 767 & 541 & & 841 & 830 & 960 & \\
\hline SD & 107.90 & 75.65 & 66.01 & 51.00 & 102.30 & 92.30 & $\begin{array}{ll}0 & 129.79\end{array}$ & 183.90 & 114.05 & 83.42 & & & & & \\
\hline III M & 492 & 675 & 653 & 661 & & 919 & 984 & 625 & 616 & 608 & & 82 & & & \\
\hline SD & 66.50 & 132.02 & & & & 130.04 & 4133.98 & & & & 47.71 & 83.42 & 117.42 & 108.20 & 141.53 \\
\hline IV M & 567 & 733 & 710 & & & 968 & 1105 & & 698 & 84 & & 1108 & 1016 & 1274 & \\
\hline SD & & 44.94 & & & & 197.54 & $4 \quad 141.30$ & & 93.51 & 9 & .79 & 61.94 & 86.86 & .91 & 6.07 \\
\hline M & 467 & 691 & 669 & & 927 & 1153 & 1145 & 567 & 733 & 1008 & 916 & 1025 & 1024 & 1347 & 1097 \\
\hline SD & 103.28 & 60.35 & 57.59 & 171.26 & 143.13 & 136.93 & 3183.19 & 45.62 & 127.00 & 155.33 & 66.50 & 132.30 & 129.84 & 176.93 & 149.57 \\
\hline VI M & 475 & 891 & 863 & 847 & 1387 & 1266 & 1185 & 1059 & 1008 & 1133 & 1226 & 1033 & 1073 & 1565 & 1137 \\
\hline SD & 92.30 & 61.94 & 74.71 & 47.71 & 133.00 & 183.42 & 2121.50 & 135.94 & 189.99 & 131.03 & 51.00 & 92.30 & 146.72 & 123.89 & 185.83 \\
\hline M & 540 & 835 & 796 & 817 & 965 & 960 & 973 & 901 & 819 & 738 & 852 & 1067 & 1023 & 981 & 1075 \\
\hline SD & 35.87 & 56.29 & 98.27 & 78.68 & 101.27 & 91.09 & 9104.64 & 101.09 & 65.20 & 74.00 & 63.91 & 108.86 & 125.68 & 86.49 & 127.44 \\
\hline
\end{tabular}

Density of glial cells: The density of glial cells in fullthickness cortical samples was greater in autism than age-matched controls andthere was no intersection of plotted curves. Collectively, samples from autistic subjects evidenced significantly greater density of glial cells in area $22(90 \%, \mathrm{p}=0.0002)$, area $39(40 \%$, $\mathrm{p}=0.0032)$ andarea $44(20 \%, \mathrm{p}=0.0262)$. Greater mean density of glial cells was evident in autism compared to controls in all six cortical layers. Plotted curves for glial density demonstrated an approximate linear increase in control cohorts in all brain areas andin area 39 of the autistic cohort. For subjects of age 7 through 10, area 22 from autistic subjects evidenced a steep linear increase between age 7 and age 10, then plateau through age 26 andarea 44 of the autistic cohort demonstrated a linear decline (Fig. 2a-c). Generally, laminar glial density in autistic subjects was greater than controls of corresponding age, although no difference was found in layer IV (granular) andlayers II and III (supragranular) of area 44. It also was noted that the autism-versus-control difference in glial density gradually diminshed between age 7 and age 31 in layers $\mathrm{V}$ and VI of area 44, while it increased in other layers (Table 2). 
Am. J. Biochem. \& Biotech., 4 (2): 130-145, 2008

Table 4: Number of cells containing lipofuscin/ $\mathrm{mm}^{2}$. M: Mean. SD: standard deviation. T: total cell density

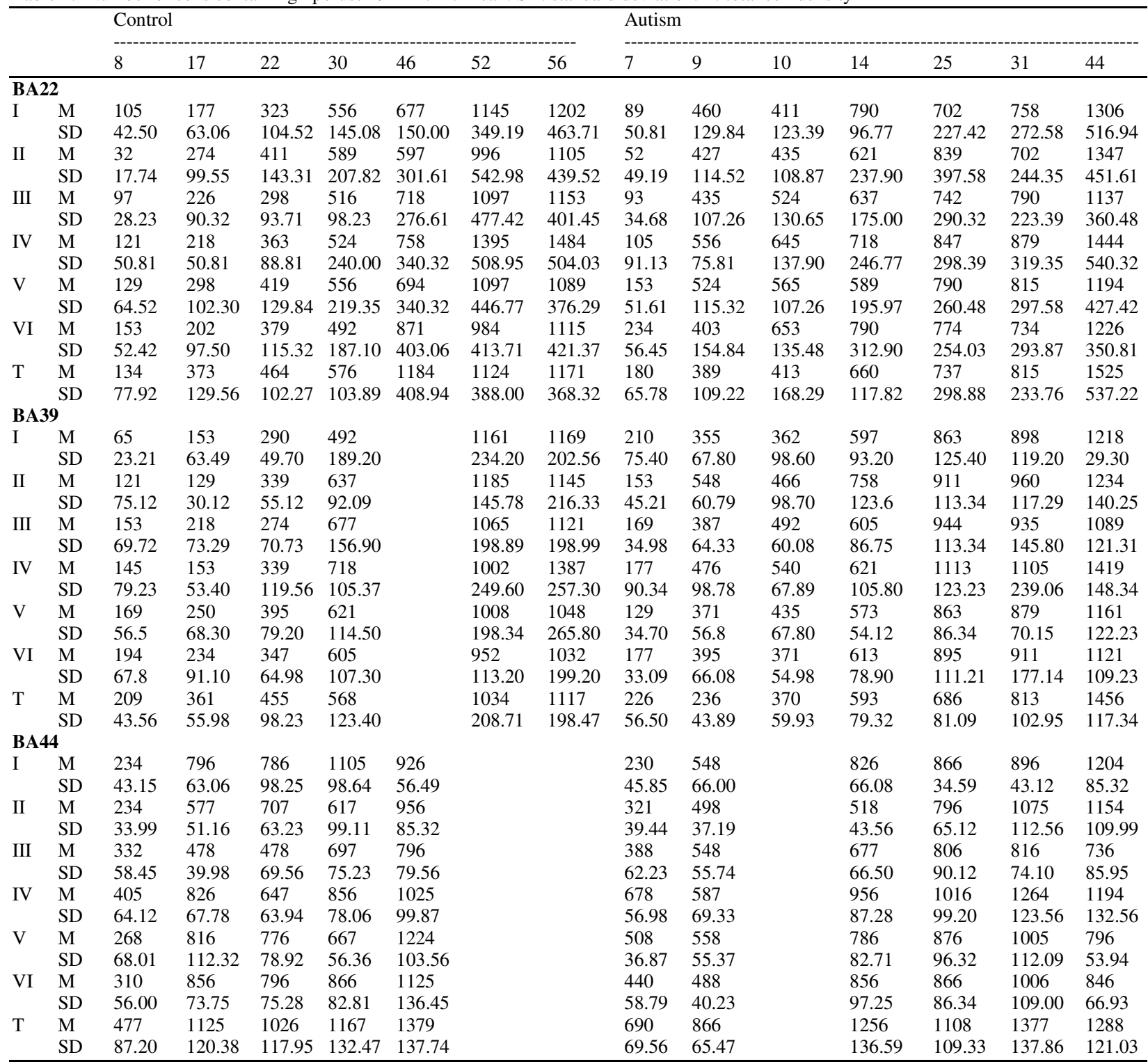

Neuronal density: Mean neuronal densities for fullthickness cortical samples were significantly reduced in the autistic cohort as compared to controls in area 22 $(38 \%$ reduction, $\mathrm{p}=0.0012)$ and area $39(24 \%$ reduction, $\mathrm{p}=0.0011)$, but no significant difference was found in area 44 . In relation to controls, decrements in neuronal density were greatest in area 22. Values in autism were lower at all corresponding ages in area 22 andall but age 7 in area 39. Steep initial declines in neuronal density from age 7 to age 10 and essential plateau thereafter in areas 22 and 39 in autism contrasted with gradual linear declines in controls (Fig. 2d-f).
In area 22 , the difference in neuronal density grew from $20 \%$ fewer neurons at age $10(\mathrm{p}=0.0132)$ to $42 \%$ fewer neurons in adolescence ( $\mathrm{p}=0.0395)$ (Fig. 2d). The greatest difference in neuronal cell density in area 22 was evident in layers II and IV (Table 3). The neuronal density in area 39 for the control group declined very little with increasing chronological age. Neuronal density in area 39 was equivalent for the youngest autistic (age 7) and control (age 8) subjects. In area 39, a steep decline in neuronal density was evident between age 7 and ages $9 / 10$ in autism (34\%; $\mathrm{p}=0.0282)$, but density in the eldest autistic subject (age 44), was not substantially lower than at ages $9 / 10$ (Fig. 2e). 

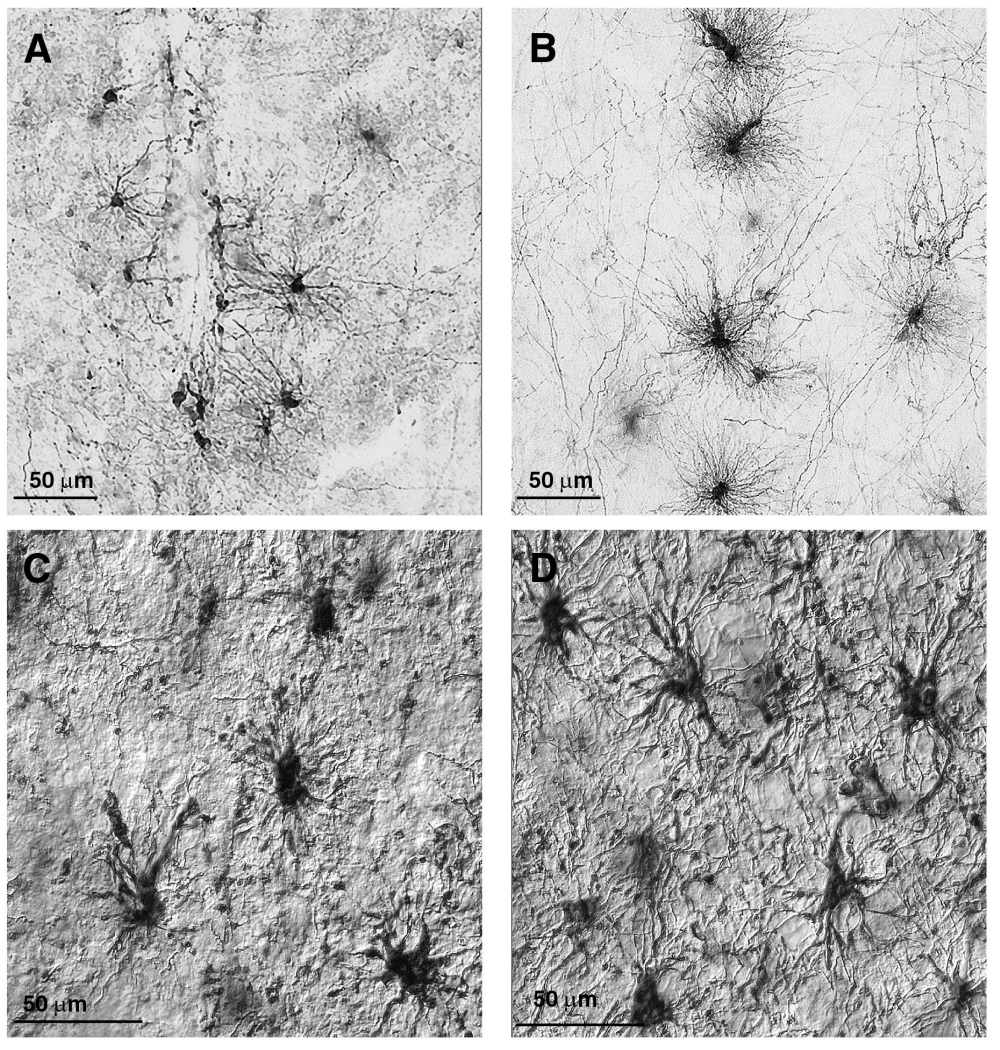

Fig. 4: Photomicrographs illustrating glial cells using immunocytochemical staining methods for the glial fibrillary acidic protein (GFAP). A and B demonstrate protoplasmic astrocytes and C and D demonstrate fibrous astrocytes. Conspicuous alterations of the morphology of the glial cells are evident in autistic patients (B and D), compared to control cases (A and C)

Laminar analysis indicated that the decrement of neurons evident in autism relative to controls at age 7 in area 22 was most pronounced in layers $\mathrm{V}$ or VI (the infragranular layer), than in layers II or III (Table 3). By age 10, the neuronal density in layer II of area 22 in autism was 53\% lower than corresponding control $(\mathrm{p}=0.0055)$. In area 44 , lower neuronal density in autism versus controls was found primarily in cortical layers II and III in younger subjects; in older subjects, decrements relative to controls were found in nearly all layers (Table 3).

Lipofuscin-containing cells: The density of lipofusincontaining cells in full-thickness cortical samples was greater in the autistic cohort than controls: area 22 $(50 \%$ greater, $\mathrm{p}=0.0007)$ and area $39(44 \%$ greater, $\mathrm{p}=0.0096)$. Other than equivalent values for the youngest of either cohort for areas 22 and 39, autistic subjects showed greater density of lipofuscincontaining cells than controls at all corresponding ages.
The youngest (age 7 years) member of the autistic cohort evidenced greater density of lipofuscincontaining cells ( $46 \%$ greater, $\mathrm{p}=0.0086)$ in area 44 than the corresponding 8-year-old control.

Relative to controls, the autistic group evidenced steep increases in the density of lipofuscin-containing cells between age 7 and 14 in all three brain areas. (Fig. 2g-i) For instance, the density of cells with lipofuscin in area 22 in autistic subjects of age 9/10 was equivalent to density in the control subject of age 17; by age 14 , the density of cells containing lipofuscin in autism were approximately twice the density in control subject of age 17. ( $<<0.0168)$ (Fig. 2g). Similar sharp rises were apparent among younger members of the autistic cohort in areas 39 and 44 . However, significant increases were not observed in area 44 in autism after age 10 (Table 4).

Laminar analysis demonstrated greater density of lipofuscin-containing cells particularly in layers II and IV in all three areas of brain (Table 4). Microscopic 
observation imparted the impression that larger lipofuscin aggregates were more concentrated in layers III and V in areas 22 and 39.

Morphological analysis of glial cells: Variant astrocyte morphology was observed in autism. In comparison to controls, both the subclass of protoplasmic astrocytes (characterized by short, thick, highly-branched processes) and the subclass of fibrous astrocytes (characterized by long, thin, less branched processes) demonstrated earlier hypertrophy of the perikaryon and processes in autism. (Fig. 4a-d) Further, the subclass of protoplasmic astrocytes exhibited larger size, denser ramification of fine processes anda fibrinoid aspect in austim that was not appreciated in control specimens (Fig. 4b).

\section{DISCUSSION}

The present autism study constitutes the first neuroanatomical analysis of diverse regions of the cerebral cortex involved in linguistic processing and production of speech, across a broad age-group. Autistic cortex was markedly altered in comparison to age-matched controls, including increased density of glial cells, decreased density of neurons andincreased density of nonspecifc lipofuscin-containing cells.

Previous reports suggest neurodevelopmental aberration in autism. Kemper and Bauman (1993) reported a coarse and poorly-laminated cingulate cortex in autism andother authors have presented functional evidence of abnormal connections, as well as a delay in the maturation of some cortical circuits ${ }^{[9-12]}$. Positron Emission Tomography (PET) and Magnetic Resonance Imaging (MRI) scans of autistic subjects suggest cortical ectopias, a distinctive feature of altered neuronal migration ${ }^{[10,13-15]}$.

The present study found no deviation from normal cortical layering pattern, evidence of ectopic cells, nor differences in the relative thickness of cortical layers in areas 22, 39 and 44 of brain from autistic subjects. If the cytoarchitectonic criteria of Benes ${ }^{[16]}$ are valid, these findings argue strongly against the hypothesis of altered neuronal migration in the neuropathogenesis of autism.

Cortical gliosis in autism: In all three brain areas (22, 39 and 44), full-thickness cortical samples from autistic subjects of all ages demonstrated greater density of glial cells in comparison to controls (up to more than double). Since thickness of the cortical layers is not altered in autistic subjects, the finding of greater glial density in autism implies a greater gross number of glial cells in each area due to cellular proliferation andnot due to reduction of neuropil volume. Proliferation of glial cells as well as the hypertrophic morphological changes in glia reported in this study are consistent with reactive gliosis in autism.

Proliferation of glial cells occurs in diverse pathologies, including ischemia, trauma, neurodegenerative disorders andsenescence ${ }^{[17-22]}$. Glial fibrillary acidic protein (GFAP), a major intermediate structural filament protein expressed predominantly in mature astrocytes, is considered a hallmark of gliosis under conditions of neuronal injury ${ }^{[23-25]}$. A marked increase in the number of neuroglial cells in the middle frontal gyrus, anterior cingulate gyrus andcerebellum of autistic patients, as well as increased inflammatory cytokines in parenchyma and cerebrospinal fluid (CSF) have been reported in autism ${ }^{[26]}$. Significantly elevated concentrations of GFAP were reported in the CSF, frontal, parietal andcerebellar cortices of children with autism $^{[27,28]}$. The results of the present study present further evidence for widespread gliosis in autism.

A toxic etiology for autism has not been excluded. Many toxins induce gliosis, including metals such as lead, iron andmercury, which specifically induce glial proliferation, degeneration anddecreased cellular function in some regions of the brain ${ }^{[29-33]}$. Neurotoxicity of metals is primarily mediated by increased oxidative stress and both increased metals and increased oxidative stress are reported in autism $^{[34,35]}$. Hypothetically, environmental exposure in sensitive subjects might underlie glial proliferation and neuronal death in the pathogenesis of autism.

Neuronal attrition in autism: Other investigators have reported reduced numbers of neurons (cerebellar Purkinje and granule cells $)^{[36-38,15]}$ in brain of subjects with autism, but there are no prior reports of decreased neurons in cerebral cortex. Coleman ${ }^{[39]}$ examined auditory brain regions, including Broca's area, from a single subject with a presumptive diagnosis of autism, but found no differences in neuronal density relative to control subjects. Magnetic resonance imaging of autistic subjects of 3-4 years of age demonstrated less n-acetyl aspartate (NAA) ${ }^{[40]}$, a metabolite produced by neurons, but not glia.

The present study employed a larger cohort of systematically diagnosed autistic subjects andfound a striking reduction in neuronal density in area 22 and 39 in autism relative to controls, including lower density of neurons in area 22 from the youngest member of the autistic cohort (age 7). Neuronal density in area 39 was equivalent in the youngest autistic subject and youngest control (age 8), suggesting that the reduced neuronal density in older autistic subjects is not explicable on the 
basis of failed genesis, but due to attrition. Loss of cortical neurons has been described in other neuropsychiatric pathologies, such as schizophrenia, bipolar disorder andmajor depressive disorder, all of which coexist with different cognitive impairments, some similar to those observed in autism ${ }^{[41-44]}$.

Decrease in density of neurons in autism was most pronounced in cortical layers II and IV. While the present study did not separately tabulate pyramidal cells and smaller neurons, its findings are comparable to decreased pyramidal cells in layers II and III and, less conspicuously, in layers $\mathrm{V}$ and VI in frontal and temporal neocortex in Rett syndrome [45], a neurodegenerative disease associated with autism ${ }^{[46-48]}$. The relationship of increased glial cell density and decreased neuronal cell density varied in autism by brain area. Increased glial density coincided with decreased neuronal numbers in area 22 and are 39, but not area 44. A significant increase in glial density in the youngest member of the autistic cohort (age 7) was associated with decreased neuronal density in area 22, but not in area 39. Determination of glial and neuronal densities in a larger cohort including younger subjects is needed to elucidate the temporal and functional relationship of these two parameters.

Indications of oxidative stress in autism: One of the more interesting findings of the present study is the significant increase of lipofuscin-containing cells in autism. Lipofuscin is classically associated with recognized neurodegenerative diseases andthere is no prior record of previous examination of brain from autistic subjects for lipofuscin. Increased lipofuscin was reported previously in brain from subjects with Rett's syndrome ${ }^{[49-51]}$.

Lipofuscin is an intralysosomal polymeric material originated from autophagocytosed cellular components that cannot be degraded or exocytosed. Biochemical analysis of lipofuscin reveals a complex aggregated byproduct composed primarily of oxidatively-modified proteins and lipids ${ }^{[52-55]}$. In addition, lipofuscin is a depot for metals, including redox-active and heavy metals ${ }^{[56]}$. Lipofuscin accumulation in cells is accelerated under conditions of oxidative stress ${ }^{[57-59]}$. Experimentally, lipofuscin itself induces neurotoxicity via generation of free-radicals ${ }^{[52-54]}$.

Several authors have proposed the involvement of free radicals andcross-linking reactions by intralysosomal degradation products, as initial steps in the formation of lipofuscin ${ }^{[58,60,61]}$. Higher levels of lipofuscin may be viewed as a marker for heightened oxidative processes which are potentially harmful to brain cells ${ }^{52]}$, or for greater oxidative damage to brain cells.
Extensive research has demonstrated that oxidative stress plays a seminal role in the pathology of several neurological diseases, including Alzheimer's disease $\mathrm{e}^{[62,63]}$, Down's syndrome ${ }^{[64]}$, Parkinson's disease $^{[65,66]}$, schizophrenia ${ }^{[67,68]}$ andbipolar affective disorder ${ }^{[69]}$. Interestingly, recent studies have reported increased free-radicals, lower levels of antioxidant proteins andgreater oxidatively modified biomolecules in peripheral samples from autistic children ${ }^{\text {[70-77] }}$.

Significantly increased numbers of lipofuscincontaining cells were found in the three brain areas of subjects with autism andwere most pronounced in area 22, which also featured the greatest increase in glial density and greatest decrease in neuronal density. Since the lipofuscin cell-count did not differentiate neurons and glia, the profile of brain cells with increased lipofuscin in autism remains undetermined. As noted earlier, the size of lipofuscin aggregates was judged greatest in layers III and V in areas 22 ad 39, which is noted to be the cite of the largest pyramidal neurons. In one area (44), increased lipofuscin was evident in the youngest of the autistic cohort (age 7), suggesting that greater lipofuscin as well as differential glial and neuronal densities may be detectable in younger autistic subjects in further studies.

The data presented are strictly phenomenological anddo not afford firm conclusions about mechanistic relationships among the three measured parameters. While the study did not determine the extent of glial (versus neuronal) lipofusin content, it is known that lipofusin appears in reactive glial cells ${ }^{[78]}$ andthat oxidative stress in glial cells alters their function ${ }^{[79,80]}$. Greater lipofuscin in brain of autistic subjects of age 7-44 probably reflects greater oxidative stress in brain, as suggested by peripheral measurements of oxidative stress in autism ${ }^{[70-72,81]}$. The increased numbers of cells containing lipofuscin may reflect (a) an environmentally-induced reactive glial response injurious to neurons, (b) an environmentally-induced direct oxidative injury to neurons, or (c) both.

In summary, the present study of language-related cortical areas 22, 39 and 44 demonstrated a greater density of glial cells, a lesser density of neurons andan increased density of non-specific lipofuscin-containing brain cells in autism. Changes in these parameters were progressive andvaried in extent by cortical area and layer.

\section{ACKNOWLEDGMENTS}

This study was supported by a grant of the National Alliance for Autism Research. We wish to thank Woody McGinnis for his assistance. 


\section{REFERENCES}

1. Ciaranello, A.L. and R.D. Ciaranello, 1995. The neurobiology of infantile autism. Ann. Rev. Neurosci., 18:101-128.

2. Folstein, S.E. and M.L. Rutter, 1988. Autism Familial aggregation and genetic implications. J. Autism. Dev. Disord., 18: 3-30.

3. Freeman, B.J., E. Ritvo, A. Mason-Brothers, C. Pingree and A. Yokata, 1989. Psychometric assessment of first-degree relatives of 62 autistic probands in Utah. Am. J. Psychiatry., 146: 361-364.

4. Rutter, M., P. Bolton, R. Harrington, A. Le Couteur, H. Macdonald and Simonoff, 1990. Genetic factors in child psychiatric disorders I. A review of research strategies. J. Child. Psychol. Psychiatry., 31: 3-37.

5. Asperger, H., 1944. Die autistischen Psychopathen im Kindesalter. Arch. Psychiatr. Nervenkr., 177: 76-137.

6. Gillberg, C., S. Steffenburg and H. Schaumann, 1991. Autism Epidemiology: Is autism more common now than 10 years ago?. Br. J. Psychiatry., 158:403-409.

7. Venter, A., C. Lord and E. Schopler, 1992. E. A follow-up study of high-functioning autistic children. J. Child. Psychol. Psychiatry, 3: 489-507.

8. Galaburda, A.M. and T.L. Kemper, 1979. Cytoarchitectonic abnormalities in developmental dyslexia: A case study. Ann. Neurol., 6: 94-100.

9. Horwitz, B., J.M. Rumsey, C.L. Grady and S.I. Rapoport, 1988. The cerebral metabolic landscape in autism. Intercorrelations of regional glucose utilization. Arch. Neurol., 45: 749-755.

10. Piven, J., M.L. Berthier, S.E. Starkstein, E. Nehme and G. Pearlson, 1990. Magnetic resonance imaging evidence for a defect of cerebral cortical development in autism. Am. J. Psychiatry, 147: 734-739.

11. Minshew, N.J., G. Goldstein, S.M. Dombrowski, K. Panchalingam and J.W. Pettegrew, 1993. A preliminary 31P MRS study of autism: evidence for undersynthesis and increased degradation of brain membranes. Biol. Psychiatry., 33: 762-773.

12. Minshew, N.J., B. Luna and J.A. Sweeney, 1999. Oculomotor evidence for neocortical systems but not cerebellar dysfunction in autism. Neurology., 52: 917-922.

13. Berthier, M.L., S.E. Starkstein and R. Leiguarda, 1990. Developmental cortical anomalies in Asperger's syndrome: Neuroradiological findings in two patients. J. Neuropsychiatry Clin. Neurosci., 2: 197-201.
14. Schifter, T., J.M. Hoffman, H.P. Hatten, M.W. Jr. Hanson, R.E. Coleman and G.R. DeLong, 1994. Neuroimaging in infantile autism. J. Child Neurol., 9: 155-161.

15. Bailey, A., P. Luthert, A. Dean, B. Harding, I. Janota, M. Montgomery, M. Rutter and P. Lantos, 1998. A clinicopathological study of autism. Brain., 121: 889-905.

16. Benes, F.M., 1988. Post-mortem structural analyses of schizophrenic brain: Study designs and the interpretation of data. Psychiatr. Dev., 6: 213-226.

17. Giulian, D. and K. Vaca, 1993. Inflammatory glia mediate delayed neuronal damage after ischemia in the central nervous system. Stroke., 24: 184-190.

18. Landis, D.M., 1994. The early reactions of nonneuronal cells to brain injury. Annu. Rev. Neurosci., 17: 133-151.

19. Kempski, O.S. and C. Volk, 1994. Neuron-glial interaction during injury and edema of the CNS. Acta Neurochir. Suppl., 60: 7-11.

20. Leuba, G. and R. Kraftsik, 1994. Visual cortex in Alzheimer's disease: occurrence of neuronal death and glial proliferation andcorrelation with pathological hallmarks. Neurobiol. Aging., 15: 29-43.

21. Nieto-Sampedro and M.F. Mora, 1994. Active microglia, sick astroglia and Alzheimer type dementias. Neuroreport., 5: 375-380.

22. Streit, W.J., 1996. The role of microglia in brain injury. Neurotoxicology, 17: 671-678.

23. Brenner, M. and A. Messin, 1996. GFAP. Transgenic Mice. Methods, 10: 351-364.

24. Raivich, G., M. Bohatschek, C.U. Kloss, A. Werner, L.L. Jones and G.W. Kreutzberg, 1999. Neuroglial activation repertoire in the injured brain: Graded response, molecular mechanisms and cues to physiological function. Brain Res. Brain Res. Rev., 30: 77-105.

25. Messing, A., M.W. Head, K. Galles, E.J. Galbreath, J.E. Goldman and M. Brenner, 1998. Fatal encephalopathy with astrocyte inclusions in GFAP transgenic mice. Am. J. Pathol., 152: 391-398.

26. Vargas, D.L., C. Nascimbene, C. Krishnan, A.W. Zimmerman and C.A. Pardo, 2005. Neuroglial activation and neuroinflammation in the brain of patients with autism. Ann. Neurol., 57: 67-81.

27. Ahlsen, G., L. Rosengren, M. Belfrage, A. Palm, K. Haglid, A. Hamberger and C. Gillberg, 1993. Glial fibrillary acidic protein in the cerebrospinal fluid of children with autism and other neuropsychiatric disorders. Biol. Psychiatry, 33: 734-743. 
28. Laurence, J.A. and S.H. Fatemi, 2005. Glial fibrillary acidic protein is elevated in superior frontal, parietal and cerebellar cortices of autistic subjects. Cerebellum., 4: 206-210.

29. Coffey, C.E., S. Alston, E.R. Heinz and P.C. Burger, 1989. Brain iron in progressive supranuclear palsy: clinical, magnetic resonance imaging andneuropathological findings. J. Neuropsychiatry Clin. Neurosci., 1: 400-404.

30. Abraham, H., A. Losonczy, G. Czeh and G. Lazar, 2001. Rapid activation of microglial cells by hypoxia, kainic acid andpotassium ions in slice preparations of the rat hippocampus. Brain Res., 906: 115-126.

31. Eskes, C., P. Honegger, L. Juillerat-Jeanneret and F. Monnet-Tschudi, 2002. Microglial reaction induced by noncytotoxic methylmercury treatment leads to neuroprotection via interactions with astrocytes and IL-6 release. Glia., 37: 43-52.

32. Zurich, M.G., C Eskes, P. Honegger, M. Berode and F. Monnet-Tschudi, 2002. Maturationdependent neurotoxicity of lead acetate in vitro: Implication of glial reactions. J. Neurosci. Res., 70: 108-116.

33. Levine, S.M. and A. Chakrabarty, 2004. The role of iron in the pathogenesis of experimental allergic encephalomyelitis and multiple sclerosis. Ann. N.Y. Acad. Sci., 1012: 252-266.

34. McGinnis, W.R., 2006. Oxidative stress in autism. Altern. Ther. Health Med., 10: 22-36.

35. Kern, J.K. and A.M. Jones, 2006. Evidence of toxicity, oxidative stress andneuronal insult in autism. J. Toxicol. Environ. Health B. Crit. Rev., 9: 485-499.

36. Williams, R.S., S.L. Hauser, D.P. Purpura, F.R. DeLong and C.N. Swisher., 1980. Autism and mental retardation. Neuropathologic studies performed in four retarded persons with autistic behavior. Arch. Neurol., 37: 749-753.

37. Ritvo, E.R., B.J. Freeman, A.B. Schiebel, T. Duong and H. Robinson, 1986. Lower Purkinje cell counts in the cerebellum of four autistic subjects: Initial findings of the UCLA-NSAC autopsy research report. Am. J. Psychiatry, 143: 862-866.

38. Kemper, T.L. and M.L. Bauman, 1993. The contribution of neuropathologic studies to the understanding of autism. Behav. Neurol., 11: $175-187$.

39. Coleman, P.D., J. Romano, L. Laphan and W. Simon, 1985. Cell counts in cerebral cortex of an autistic patient. J. Autism Dev. Disord., 15: $245-255$.
40. Friedman, S.D., D.W. Shaw, A.A. Artru, T.L. Richards, J. Gardner, G. Dawson, S. Posse and S.R. Dager, 2003. Regional brain chemical alterations in young children with autism spectrum disorder. Neurology, 60: 100-107.

41. Rajkowska, G., 2000. Postmortem studies in mood disorders indicate altered numbers of neurons and glial cells. Biol. Psychiatry, 48: 766-777.

42. Benes, F.M., S.L. Vincent and M. Todtenkopf, 2001. The density of pyramidal and nonpyramidal neurons in anterior cingulate cortex of schizophrenic and bipolar subjects. Biol. Psychiatry, 50: 395-406.

43. Rajkowska, G., A. Halaris and L.D. Selemon, 2001. Reductions in neuronal and glial density characterize the dorsolateral prefrontal cortex in bipolar disorder. Biol. Psychiatry, 49: 741-752.

44. Selemon, L.D. and G. Rajkowska., 2003. Cellular pathology in the dorsolateral prefrontal cortex distinguishes schizophrenia from bipolar disorder. Curr. Mol. Med., 3: 427-436.

45. Belichenko, P.V., B. Hagberg and A. Dahlstrom, 1997. Morphological study of neocortical areas in Rett syndrome. Acta Neuropathol., 93: 50-61.

46. Hagberg, G., J. Aicardi, K. Dias and O. Ramos, 1983. A progressive syndrome of autism, dementia, ataxia andloss of purposeful hand use in girls: Rett's syndrome: Report of 35 cases. Ann. Neurol., 14: 470-471.

47. Hagberg, B., 1985. Rett's syndrome: Prevalence and impact on progressive severe mental retardation in girls. Acta Paediatr. Scand., 74: 405-408.

48. Trevathan, E. and S. Naidu, 1988. The clinical recognition and differential diagnosis of Rett syndrome. J. Child Neurol., 3: 6-16.

49. Jellinger, F. and Seitelberger, 1986. Neuropathology of Rett syndrome. Am. J. Med. Genet. Suppl., 1: 259-288.

50. Jellinger, K., D. Armstrong, H.Y. Zoghbi and A.K. Percy, 1988. Neuropathology of Rett syndrome. Acta Neuropathol., 76: 142-158.

51. Cornford, M.E., M. Philippart, B. Jacobs, A.B. Scheibel and H.V. Vinters, 1994. Neuropathology of Rett syndrome: case report with neuronal and mitochondrial abnormalities in the brain. J. Child Neurol., 9: 424-431.

52. Brunk, U.T. and A. Terman, 2002. The mitochondrial-lysosomal axis theory of aging: Accumulation of damaged mitochondria as a result of imperfect autophagocytosis. Eur. J. Biochem., 269: 1996-2002. 
53. Brunk, U.T. and A. Terman, 2002. Lipofuscin mechanisms of age-related accumulation and influence on cell function. Free Radic. Biol. Med., 33: 611-619.

54. Szweda, P.A., M. Camouse, K.C. Lundberg, T.D. Oberley and L.I. Szweda, 2003. Aging, lipofuscin formation andfree radical-mediated inhibition of cellular proteolytic systems. Ageing Res. Rev., 2:383-405.

55. Terman, A. and U.T. Brunk., 2004. Lipofuscin. Int. J. Biochem. Cell. Biol., 36:1400-1404.

56. Jolly, R.D., B.V. Douglas, P.M. Davey and J.E. Roiri, 1995. Lipofuscin in bovine muscle and brain: a model for studying age pigment. Gerontology, 41: 283-295.

57. Sohal, R.S. and U.T. Brunk, 1989. Lipofuscin as an indicator of oxidative stress and aging. Adv. Exp. Med. Biol., 266: 17-26.

58. Brunk, U.T., C.B. Jones and R.S. Sohal, 1992. A novel hypothesis of lipofuscinogenesis and cellular aging based on interactions between oxidative stress and autophagocytosis. Mutat. Res., 275: 395-403.

59. Gao, G., K. Ollinger and U.T. Brunk, 1994. Influence of intracellular glutathione concentration of lipofuscin accumulation in cultured neonatal rat cardiac myocytes. Free Radic Biol. Med., 16: 187-194.

60. Shimasaki, H., R. Maeba, R. Tachibana and N. Ueta, 1995. Lipid peroxidation and ceroid accumulation in macrophages cultured with oxidized low density lipoprotein. Gerontology, 41: 39-51.

61. Grune, T., T. Reinheckel and K.J. Davies, 1997. Degradation of oxidized proteins in mammalian cells. FASEB J., 11: 526-534.

62. Stojanovic, A., A.E. Roher and M.J. Ball, 1994. Quantitative analysis of lipofuscin and neurofibrillary tangles in the hippocampal neurons of Alzheimer disease brains. Dementia, 5: 229-233.

63. Christen, Y., 2000. Oxidative stress and Alzheimer disease. Am. J. Clin. Nutr., 71: 621S-629S.

64. Kannan, K. and S.K. Jain, 2000. Oxidative stress and apoptosis. Pathophysiology, 7: 153-163.

65. Bostantjopoulou, S., G. Kyriazis, Z. Katsarou, G. Kiosseoglou, A. Kazis and G. Mentenopoulos, 1997. Superoxide dismutase activity in early and advanced Parkinson's disease. Funct. Neurol., 12: 63-68.

66. Torsdottir, G., J. Kristinsson, S. Sveinbjornsdottir, J. Snaedal and T. Johannesson, 1999. Copper, ceruloplasmin, superoxide dismutase and iron parameters in Parkinson's disease. Pharmacol. Toxicol, 85:239-243.
67. Herken, H., E. Uz, H. Ozyurt, S. Sogut, O. Virit and O. Akyol, 2001. Evidence that the activities of erythrocyte free radical scavenging enzymes and the products of lipid peroxidation are increased in different forms of schizophrenia. Mol. Psychiatry, 6: 66-73.

68. Akyol, O., H. Herken, E. Uz, E. Fadillioglu, S. Unal, S. Sogut, H. Ozyurt and H.A. Savas, 2002. The indices of endogenous oxidative and antioxidative processes in plasma from schizophrenic patients. The possible role of oxidant/antioxidant imbalance. Prog. Neuropsychopharmacol. Biol. Psychiatry, 26: 995-1005.

69. Yanik, M., H. Vural, H. Tutkun, S.S. Zoroglu, H.A. Savas, H. Herken, A. Kocyigit, H. Keles and O. Akyol, 2004. The role of the arginine-nitric oxide pathway in the pathogenesis of bipolar affective disorder. Eur. Arch. Psychiatry Clin. Neurosci., 254: 43-47.

70. Yorbik, O., A. Sayal, C. Akay, D.I. Akbiyik and T. Sohmen, 2002. Investigation of antioxidant enzymes in children with autistic disorder. Prostaglandins Leukot. Essent. Fatty Acids, 67: 341-343.

71. Sogut, S., S.S. Zoroglu, H. Ozyurt, H.R. Yilmaz, F. Ozugurlu, E. Sivasli, O. Yetkin, M. Yanik, H. Tutkun, H.A. Savas, M. Tarakcioglu and O. Akyol, 2003. Changes in nitric oxide levels and antioxidant enzyme activities may have a role in the pathophysiological mechanisms involved in autism. Clin. Chim. Acta, 331: 111-117.

72. Zoroglu, S.S., F. Armutcu, S. Ozen, A. Gurel, E. Sivasli, O. Yetkin and I. Meram, 2004. Increased oxidative stress and altered activities of erythrocyte free radical scavenging enzymes in autism. Eur. Arch. Psychiatry Clin. Neurosci., 254: 143-147.

73. Chauhan, A., V. Chauhan, W.T. Brown and I. Cohen, 2004. Oxidative stress in autism: Increased lipid peroxidation and reduced serum levels of ceruloplasmin and transferrin-the antioxidant proteins. Life Sci., 75: 2539-2549.

74. James, S.J., P. Cutler, S. Melnyk, S. Jernigan, L. Janak, D.W. Gaylor and J.A. Neubrander, 2004. Metabolic biomarkers of increased oxidative stress and impaired methylation capacity in children with autism. Am. J. Clin. Nutr., 80: 1611-1617.

75. Ming, X., T.P. Stein, M. Brimacombe, W.G. Johnson, G.H. Lambert and G.C. Wagner, 2005. Increased excretion of a lipid peroxidation biomarker in autism. Prostaglandins Leukot. Essent. Fatty Acids, 73: 379-384. 
76. Yao, Y., W.J. Walsh, W.R. McGinnis and D. Pratico, 2006. Altered vascular phenotype in autism: correlation with oxidative stress. Arch. Neurol., 63: 1161-1164.

77. James, S.J., S. Melnyk, S. Jernigan, M.A. Cleves, C.H. Halsted, D.H. Wong, P. Cutler, K. Bock, M. Boris, J.J. Bradstreet, S.M. Baker and D.W. Gaylor, 2006. Metabolic endophenotype and related genotypes are associated with oxidative stress in children with autism. Am. J. Med. Genet. B. Neuropsychiatr. Genet., 141: 947-956.

78. Hilbig, H., H.J. Bidmon, S. Steingruber, H. Reinke and H.R. Dinse, 2002. Enriched environmental conditions reverse age-dependent gliosis and losses of neurofilaments and extracellular matrix components but do not alter lipofuscin accumulation in the hindlimb area of the aging rat brain. J. Chem. Neuroanat., 23: 199-209.
79. Stolzing, A. and T. Grune, 2003. Impairment of protein homeostasis and decline of proteasome activity in microglial cells from adult Wistar rats. J. Neurosci. Res., 71: 264-271.

80. Teoh, C.Y. and K.J. Davies, 2004. Potential roles of protein oxidation and the immunoproteasome in MHC class I antigen presentation: The PrOxI hypothesis. Arch. Biochem. Biophys, 423: 88-96.

81. Chauhan, A. and V. Chauhan, 2006. Oxidative stress in autism. Pathophysiology, 13: 171-181. 